\title{
THE BEGINNINGS OF DISCIPLINARY RESPONSIBILITy OF POLISH STATE OfFicials
}

\author{
POCZĄTKI ODPOWIEDZIALNOŚCI \\ DYSCYPLINARNEJ POLSKICH FUNKCJONARIUSZY \\ PAŃSTWOWYCH
}

\begin{abstract}
\section{Objectives}

Disciplinary liability, implemented in the form of a peer tribunal, judging the inappropriate behaviour of members of a particular corporation, was born on our continent along with the formation of the rule of law. Regulations relating to state officials in Poland were later created due to the weakness of the native clerical corps in the pre-partition period. The first Polish regulations governing the liability of state officials were created in the years 1918 - 1922. The purpose of the work is to show the creation process of disciplinary provisions regulating the disciplinary liability of title officials.
\end{abstract}

\section{Material and methods}

The studies uses a number of unpublished source materials, which have been subjected to detailed analysis.

\section{Results}

As a result of the conducted research, a number of interesting findings were obtained, which became the basis for the development of the presented text.

\section{Conclusions}

The disciplinary law in Poland was born later than other branches of law. Due to the thinness of the clerical corps in the pre-partition period, the disciplinary provisions in relation to this professional group were not sufficiently separated 
from the entire legal system. However, there were regulations in relation to several other categories of employees treated in a special way. The process of birth of disciplinary law against the title officials began in 1918.

\section{STRESZCZENIE}

\section{Cel pracy}

Odpowiedzialność dyscyplinarna, realizowana w formie sądu koleżeńskiego, który ocenia niewłaściwe zachowanie członków danej korporacji, narodziła się na naszym kontynencie wraz z powstaniem państwa prawnego. Przepisy dotyczące urzędników państwowych w Polsce powstały później ze względu na słabość rodzimego korpusu urzędniczego w okresie przedrozbiorowym. Pierwsze polskie regulacje dotyczące odpowiedzialności urzędników państwowych powstały w latach 1918-1922. Celem pracy jest ukazanie procesu narodzin przepisów dyscyplinarnych regulujących odpowiedzialność dyscyplinarną tytułowych urzędników.

\section{Material i metody}

W pracy wykorzystano niepublikowane materiały źródłowe, które zostały poddane szczegółowej analizie.

\section{Wyniki}

W wyniku przeprowadzonych badań uzyskano wiele interesujących ustaleń, które stały się podstawą opracowania prezentowanego tekstu.

\section{Wnioski}

Prawo dyscyplinarne na ziemiach polskich narodziło się później niż pozostałe gałęzie prawa. Ze względu na szczupłość korpusu urzędniczego w okresie przedrozbiorowym przepisy dyscyplinarne w odniesieniu do tej grupy zawodowej nie zostały dostatecznie wyodrębnione $\mathrm{z}$ całości systemu prawa. Istniały natomiast regulacje $\mathrm{w}$ stosunku do kilku innych kategorii pracowników potraktowanych w sposób szczególny. Proces narodzin prawa dyscyplinarnego w stosunku do tytułowych urzędników rozpoczął się w 1918 roku.

KEYWORDS: pre-partition Poland, the interwar period, new branches of law, disciplinary law, government officials.

SŁowA KLUCzowe: Polska przedrozbiorowa, okres dwudziestolecia międzywojennego, nowe gałęzie prawa, prawo dyscyplinarne, urzędnicy państwowi.

\section{WPROWADZENIE}

Mówiąc o delikcie dyscyplinarnym, mamy na myśli przewinienia zawodowe czy służbowe dokonywane przez członków określonej grupy zawodowej. W dążeniu do zapewnienia przestrzegania zasad wykonywania danego 
zawodu, w tym również zasad etycznych, powierza się członkom danej grupy zawodowej obowiązek czuwania nad nienaruszalnością reguł poprzez prawo do wymierzania sprawiedliwości naruszającym zasady.

Pisząc o pociąganiu do odpowiedzialności dyscyplinarnej, analizujemy proces reakcji przedstawicieli danej profesji na naruszenie zasad wykonywania zawodu, w tym również norm etycznych. Regułą przy tym jest, że odpowiedzialność tego typu jest egzekwowana przez pracowników równych stanowiskiem osobie popełniającej delikt dyscyplinarny. Wyjątek stanowią służby mundurowe, wobec których dopuszcza się w większym stopniu udział przełożonych w procesie egzekwowania odpowiedzialności służbowej (Bek, 2019, s. 249).

W polskiej doktrynie przyjmowano dotychczas raczej zgodnie, że odpowiedzialność dyscyplinarna, realizowana w postaci sądu koleżeńskiego oceniającego niewłaściwe zachowanie członków danej korporacji, narodziła się na naszym kontynencie w XIX wieku wraz z ukształtowaniem się państwa prawnego (Leoński, 1959, s. 16-17; Bek, 2019, s. 11). Byłby to więc stosunkowo nowy rodzaj odpowiedzialności. W polskim systemie prawnym zaistniała ona dopiero $\mathrm{w}$ dwudziestoleciu międzywojennym po odzyskaniu niepodległości (Giętkowski, 2013, s. 19-21), jednak na ziemiach polskich była znana poprzez regulacje państw zaborczych. Szczególnie w zaborze pruskim i austriackim (później austro-węgierskim) prawodawstwo dotyczące tego rodzaju odpowiedzialności stało na wysokim poziomie, obejmując swoim zakresem urzędników państwowych, sędziów, żołnierzy, samorządowców, adwokatów, lekarzy i wykładowców (Giętkowski, 2013, s. 20-21).

Warto jednak zauważyć, że początków odpowiedzialności dyscyplinarnej należy poszukiwać znacznie wcześniej - w monarchiach absolutnych znaczący rozwój struktur biurokratycznych wymusił na władcy rezygnację z osobistego sądzenia i karania podległych mu urzędników już w okresie wczesnonowożytnym. W konsekwencji poważne przypadki naruszenia prawa poddano orzecznictwu sądów, drobniejsze wykroczenia zaś, wynikające $\mathrm{z}$ niedopełnienia obowiązków, lub przekroczenia uprawnień przekazano przełożonym oraz tworzonym na podstawie odrębnych przepisów organom kolegialnym. Znajdowały się one wewnątrz struktur biurokratycznych, były wzorowane na sądach, zasiadali w nich zaś wybrani urzędnicy (Giętkowski, 2013, s. 21-22). 
Wcześniej podobne procesy zachodziły już w strukturach wojskowych, gdzie stopniowo rozdzielono jednolitą dotychczas władzę sądzenia i karania żołnierzy przez ich dowódców na odpowiedzialność karną przed sądami i odpowiedzialność zbliżoną do odpowiedzialności dyscyplinarnej ponoszoną przed przełożonymi oraz koleżeńskimi sądami honorowymi. Co prawda w tym przypadku nie można mówić o takim stopniu samodzielności i niezależności, jak w przypadku sądów urzędniczych, ale niewątpliwie mieliśmy do czynienia z pewną formą odpowiedzialności dyscyplinarnej (Leoński, 1959, s. 18-19).

Jeszcze dalej, gdyż do średniowiecza, powinniśmy się cofnąć, poszukując początków odpowiedzialności dyscyplinarnej studentów oraz wykładowców. I w tym samym okresie należy upatrywać narodzin tytułowej odpowiedzialności członków samorządów zawodowych kształtujących się wówczas korporacji (Grelowski, 1947, s. 52-53).

\section{ODPOWIEDZIALNOŚĆ DYSCYPLINARNA W Przedrozbiorowej Polsce}

W przedrozbiorowej Polsce aparat urzędniczy był tak słaby i nieliczny w porównaniu do tego funkcjonującego w państwach ościennych, że wskazane procesy nie mogły zachodzić z porównywalną dynamiką, jednak możemy zauważyć pewne symptomy zjawisk, które stały się w przyszłości wzorcem w budowie własnego systemu odpowiedzialności dyscyplinarnej.

Średniowieczne korporacje zawodowe, zwłaszcza rzemieślnicze i kupieckie, cieszyły się również w Polsce znacznym stopniem samodzielności, który wyrażał się między innymi prawem do karania swoich członków w przypadkach przewinień ściśle określonych w przywilejach. To w łonie tych grup zawodowych doszukujemy się pierwszych oznak niezależności w kwestii wymierzania sprawiedliwości swoim członkom przez pozostałych uczestników samorządu na ziemiach polskich (Bek, 2019, s. 10-12).

Szerokie uprawnienia $\mathrm{w}$ zakresie samodzielnego orzekania w sprawach dyscyplinarnych nadawali rządzący nowo tworzonym uczelniom. W dokumencie erekcyjnym z 1364 r. król Kazimierz gwarantował studentom prawo do ich własnego rektora, którego będą wybierać $\mathrm{z}$ własnego grona, sprawującego nad nimi władzę sądową w ściśle określonych przypadkach. Miała ona obejmować w pierwszej i ostatniej instancji lekkie sprawy karne, typu 
znieważenie, naruszenie nietykalności cielesnej czy bójka między studentami. W pierwszej instancji zaś, z zachowaniem prawa do apelacji (Morawski, 1900, s. 33-34), również poważniejsze przestępstwa, typu kradzież, cudzołóstwo czy zabójstwo. W każdym przypadku rektor miał być zawiadamiany, jeśli w stosunku do studentów lub pracowników uczelni prowadzono postępowanie karne. Ściganie zaś i więzienie podległych mu osób wymagało jego zgody (Morawski, 1900, s. 34-35).

Zakres tej władzy w stosunku do uczelni krakowskiej uległ z czasem rozszerzeniu ze względu na liczbę spraw, jakie stamtąd napływały do sądu biskupiego, zaprzątając uwagę kościelnego dostojnika. Dlatego zawiadujący diecezją krakowską biskup Zbigniew Oleśnicki delegował część swojej władzy sądowej w 1448 r., nadając rektorowi uprawnienie do orzekania również w sprawach ciężkich przestępstw bez odsyłania ich do sądu biskupiego (Morawski, 1900, s. 453-454).

Podobne rozwiązania przyjęto w tworzonej u schyłku XVI stulecia Akademii Zamojskiej, której rektor zyskał prawo do sądzenia studentów w sprawach dyscyplinarnych bez możliwości apelowania, w przypadku profesorów zaś z możliwością odwołania od wyroku do sądu biskupa chełmskiego. Ważnym elementem samorządności pozostawało w tym przypadku prawo asystowania przy orzekaniu, a potem też wykonywaniu kar dyscyplinarnych przez kolegium radnych pochodzących z grona studentów różnych nacji (Wadowski, 1899-1900, s. 95).

Później natomiast możemy zauważyć istnienie wyodrębnionego rodzaju odpowiedzialności dyscyplinarnej w wojsku. Nie jest to co prawda wystarczająco wyraźny podział na przestępstwa wojskowe i przewinienia dyscyplinarne w dzisiejszym tego słowa znaczeniu, jednak w doktrynie przyjęło się uważać, iż rozróżnienie takie istniało, a zatem w pełni zasadne jest posługiwanie się tego typu terminologią (Muszyński, 1967, s. 103). Już w XVI-wiecznym prawie wojskowym określono zasady karania żołnierzy dopuszczających się drobniejszych wykroczeń w związku z pełnioną służbą. W takim przypadku należało odstąpić od obowiązku powołania sądu wojskowego, wymierzenie kary powierzono zaś dowódcom wojskowym, przełożonym nad żołnierzami dopuszczającymi się deliktu dyscyplinarnego (Kamiński, 1928, s. 128-129; Ciesielski, 2009, s. 391). 
Nadmierna surowość uprawnionych do karania tego typu wykroczeń, niekiedy połączona ze swobodnym określaniem zakresu czynów oraz dolegliwości kar, wymusiła w dobie Oświecenia zmiany w systemie sądownictwa wojskowego. Kodeksy przyjmowane w drugiej połowie XVIII w. zawierają wiele ograniczeń. Decyzja o ukaraniu żołnierza musiała być wydana na piśmie w formie wyroku podpisanego przed egzekucją, dolegliwość orzeczonej kary nie mogła zaś przekraczać ustalonej w prawie granicy (Proceder prawny, 1775, pkt 9, gdzie znaleźć można następujące zastrzeżenie: „Na małe tylko występki, za które to stanie na kołkach, w łańcuszki zamknięcie, bieganie przez rózgi przez wach - paradę i 12 razy przez 200 ludzi jest kara dostarczająca, nie bywa krygsrecht komenderowany, ale szef lub komendant regimentu gdy rzecz jasna nieodwłocznie szpruch (wyrok) napisać każe i ten sam podpisawszy egzekucję nakaże").

\section{ODPOWIEDZIALNOŚĆ DYSCYPLINARNA W OKRESIE II RP}

Proces rozwoju prawa dyscyplinarnego $\mathrm{w}$ analizowanych latach dokonywał się w trzech okresach: okres korzystania z rozwiązań państw zaborczych; czas budowy rodzimych rozwiązań; okres zmian po przewrocie majowym.

Istnienie pierwszego $\mathrm{z}$ wymienionych wynikało wprost $\mathrm{z}$ zaszłości historycznych. Trwał on stosunkowo krótko, gdyż władze niepodległego państwa polskiego starały się wprowadzić własne regulacje dotyczące odpowiedzialności dyscyplinarnej, obowiązujące na terytorium całego kraju. Jednak proces kodyfikacji nie postępował tak szybko, jak życzyliby sobie sami zainteresowani.

Pierwsze przepisy dyscyplinarne dla polskich urzędników państwowych wprowadzono jeszcze przed odzyskaniem niepodległości reskryptem Rady Regencyjnej Królestwa Polskiego z 11.6.1918 r. (Dziennik Praw Królestwa Polskiego, nr 6, poz. 13). Analiza porównawcza przyjętych rozwiązań pozwala na stwierdzenie, że były one wzorowane na regulacjach austriackich zawartych w przepisach o postępowaniu dyscyplinarnym wobec urzędników z 1860 r. (Kaiseriche, 1860, nr 64).

W myśl przedmiotowych przepisów odpowiedzialność dyscyplinarną urzędnik ponosił niezależnie od ewentualnej odpowiedzialności karno-sądowej. Odpowiadał za swoje nieprawidłowe postępowanie, uchybienie obo- 
wiązkom służbowym oraz wykroczenie lub przestępstwo służbowe. Katalog kar obejmował dziewięć grup sankcji: upomnienie, grzywnę do 100 marek, odmówienie urlopu, naganę, wstrzymanie awansu, translokację do innej miejscowości, przeniesienie na urząd niższej kategorii płacy, złożenie z urzędu (tzw. dymisja bez prośby) oraz wydalenie ze służby.

Pierwsze trzy z wymienionych traktowano jako kary porządkowe, które mogły wymierzać nie tylko komisje dyscyplinarne, ale również naczelnicy danej jednostki organizacyjnej. Postępowanie dyscyplinarne miało być dwuinstancyjne, dlatego też utworzono dwustopniowe komisje dyscyplinarne, od decyzji zwierzchnika o nałożeniu kary porządkowej przysługiwało zaś uprawnienie do odwołania do szefa organu nadrzędnego.

W praktyce orzeczniczej pierwszych lat istnienia niepodległego państwa polskiego pojawiło się wiele problemów wynikających z nieprecyzyjności wcześniejszych przepisów. Wzmiankując o nieprawidłowym postępowaniu urzędnika, jako podlegającym ocenie pod kątem odpowiedzialności dyscyplinarnej, nie określono, czy obejmuje ono również zachowanie poza miejscem pracy (Pisma różne, 1921, k. 2-4). Organy dyscyplinarne traktowały ten przepis rozszerzająco, wymagając od funkcjonariuszy publicznych godnej postawy w każdych okolicznościach, zarówno gdy występowali w roli urzędników, jak i prywatnie (Instrukcje, k. 1-4).

Wprowadzenie rozróżnienia kar, z możliwością stosowania osobiście przez zwierzchników tych mniej dotkliwych, różnicowało ciężar deliktu dyscyplinarnego, ale nie określono, za jaki rodzaj zaniedbań ponosiło się tę, a nie inną karę (w art. 35 Reskryptu Rady jest mowa o tym, że „W przypadkach cięższego przewinienia sprawa zostaje skierowana do Komisji dyscyplinarnej, która ma prawo orzekać w wymierzaniu wszystkich kar, w art. 33 wyliczonych").

Naprzeciw tym problemom wychodziła ustawa z 17.2.1922 r. o państwowej służbie cywilnej (Dz.U. z 1922 r. nr 21, poz. 164) (dalej: ustawa o psc). Odróżniała ona odpowiedzialność dyscyplinarną od porządkowej. Tę pierwszą urzędnik ponosił za występki służbowe, tę drugą zaś za wykroczenia służbowe. Występkiem służbowym określono naruszenie obowiązków służbowych, które powodują obrazę interesu publicznego lub narażają na szkodę dobro publiczne. 
Wykroczeniem zaś było każde naruszenie obowiązku służbowego, nieposiadające wyżej wskazanych znamion występku. Przy czym zbieg kilku wykroczeń, powtarzanie się ich lub też popełnienie ich w okolicznościach szczególnie obciążających miało być traktowane jak występek służbowy.

W stosunku do poprzedniej regulacji okrojono katalog kar porządkowych - obecnie miały to być tylko upomnienie oraz skrócenie lub odmowa urlopu wypoczynkowego. Nadal jednak do ich wymierzania upoważnieni byli zwierzchnicy popełniających wykroczenie służbowe urzędników, jeśli w sprawie nie wszczęto jeszcze postępowania przed właściwą komisją dyscyplinarną.

Za występki służbowe przewidziano zmodyfikowany katalog kar dyscyplinarnych: naganę, odliczenie lat służby od roku do 3 lat, obniżenie stopnia służbowego z zawieszeniem możliwości awansu do 3 lat, przeniesienie w stały stan spoczynku z umniejszeniem uposażenia emerytalnego do 50\% oraz wydalenie ze służby - pociągające za sobą utratę praw emerytalnych (art. 77 ustawy o psc, patrz jednak art. 83 tejże „Członkom rodziny wydalonego można w razie okoliczności, zasługujących na szczególne uzasadnienie, przyznać w orzeczeniu odpowiedni zasiłek na utrzymanie, który jednak nie może przewyższać normalnego ich zaopatrzenia wdowiego lub sierocego. Zasiłek taki przyznać można albo już z chwilą wstrzymania wypłaty uposażenia urzędnika wydalonego, albo od chwili jego śmierci”).

Odpowiedzialność dyscyplinarną ponosili urzędnicy, którzy naruszyli obowiązki swego stanowiska i urzędu, zarówno pozostając w służbie, jak i poza nią, zarówno przez czyn, zaniechanie, jak i zaniedbanie. Popełnienie deliktu dyscyplinarnego $\mathrm{w}$ warunkach pozostawania poza służbą rozumiano szeroko, a więc zarówno sytuację, gdy niegodne zachowanie urzędnika miało miejsce poza miejscem wykonywania obowiązków służbowych, jak i po godzinach pracy.

Odpowiedzialność dyscyplinarną mogli również ponosić urzędnicy w stanie nieczynnym co do występków popełnionych wcześniej, czyli w czasie służby czynnej, albo jeśli popełnili czyny wypełniające znamiona występku służbowego już po odejściu w stan nieczynny. W takich przypadkach katalog sankcji musiał zostać skrócony i obejmował: naganę, zmniejszenie uposażenia (stałe lub czasowe) pobieranego w stanie nieczynnym maksymalnie 
o $25 \%$ oraz utratę wszelkich praw nabytych w trakcie trwania stosunku służbowego (również uposażenia członków rodziny), ale w przypadkach szczególnie obciążających urzędnika.

Odrębną ustawą określono strukturę organów dyscyplinarnych, zajmujących się orzekaniem w sprawach urzędników oraz zasady postępowania przed nimi (ustawa z 17.2.1922 r. o organizacji władz dyscyplinarnych i postępowaniu dyscyplinarnym przeciwko funkcjonariuszom państwowym, Dz.U. z 1922 r. nr 21, poz. 165). Stopniowo opracowywano również przepisy dyscyplinarne regulujące tytułową odpowiedzialność w stosunku do innych grup zawodowych, które w kolejnych latach doprowadziły do powstania rozwiniętego systemu obejmującego swym zasięgiem coraz większą rzeszę obywateli II Rzeczypospolitej.

\section{Podsumowanie}

Reasumując te krótkie rozważania, należy stwierdzić, że prawo dyscyplinarne na ziemiach polskich narodziło się później niż pozostałe gałęzie prawa. Ze względu na szczupłość korpusu urzędniczego w okresie przedrozbiorowym przepisy dyscyplinarne w odniesieniu do tej grupy zawodowej nie zostały dostatecznie wyodrębnione z całości systemu prawa. Istniały natomiast regulacje w stosunku do kilku innych kategorii pracowników potraktowanych w sposób szczególny.

Prawo dyscyplinarne ze swej natury bowiem ma zastosowanie tylko do pewnych grup osób wykonujących określony zawód lub pełniących daną funkcję w społeczeństwie. Zakres ponoszonej w ramach tego prawa odpowiedzialności, katalog kar i stosowanych środków różni się w zależności od przynależności do konkretnej grupy. Dlatego też rozwój tej gałęzi prawa jest ściśle uzależniony od stopnia ukształtowania danego zawodu, jego odrębności, zakresu samorządności, a także roli w społeczeństwie.

\section{Bibliografia:}

Bek D. i in. (2019). Odpowiedzialność dyscyplinarna w systemie polskiego prawa represyjnego. Analiza aspektów materianoprawnych na przykładzie wybranych pragmatyk zawodowych, Warszawa: Wydawnictwo Poltext. ISBN 9788375619829.

Ciesielski T. (2009). Armia Koronna w czasach Augusta III, Warszawa: Wydawnictwo DiG. ISBN 9788371815843. 
Giętkowski R. (2013). Odpowiedzialność dyscyplinarna w prawie polskim, Gdańsk: Wydawnictwo Uniwersytetu Gdańskiego. ISBN 9788378651246.

Grelowski Z. (1947). Samorzad specjalny, gospodarczy - zawodowy - wyznaniowy według obowiązujacych ustaw w Polsce, Katowice: Wydawnictwo Społem.

Kamiński J. (1928). Historia sadownictwa wojskowego $w$ dawnej Polsce, Warszawa: Towarzystwo Wiedzy Wojskowej.

Leoński Z. (1956). Odpowiedzialność dyscyplinarna słuchaczy państwowych szkót wyższych w prawie polskim, Zeszyty Naukowe UAM, z. I, s. 131-142.

Leoński Z. (1959). Odpowiedzialność dyscyplinarna w prawie Polski Ludowej, Poznań: Państwowe Wydawnictwo Naukowe.

Morawski K. (1900). Historya Uniwersytetu Jagiellońskiego, Kraków: Wydawnictwo Uniwersytetu Jagiellońskiego.

Muszyński J. (1967). Przestępstwo wojskowe a przewinienie dyscyplinarne w polskim prawie wojskowym, Warszawa: Wydawnictwo Ministerstwa Obrony Narodowej.

Wadowski J.A. (1899-1900), Wiadomość o profesorach Akademii Zamojskiej. Warszawa: Gazeta Rolnicza.

\section{Inne źródła}

Instrukcje w sprawach dyscyplinarnych, druk Archiwum Akt Nowych, zespół Ministerstwo Skarbu w Warszawie, sygn. 440.

Kaiserliche Verordnung vom 10 märz 1860 über die Disciplinary Behandlung der k.k. Beamten und Diener, Reichs-Gesetz-Blatt für das Kaiserthum Österreich, 1860, nr 64.

Pisma różne w sprawach dyscyplinarnych $z 1921$ r., Archiwum Państwowe w Łucku, fond 1, opis 1a, dieło 297.

Proceder prawny wojskowy, Warszawa 1775.

Reskrypt Rady Regencyjnej Królestwa Polskiego z 11.6.1918 r., Dziennik Praw Królestwa Polskiego, nr 6, poz. 13.

Ustawa z 17.2.1922 r. o organizacji władz dyscyplinarnych i postępowaniu dyscyplinarnym przeciwko funkcjonariuszom państwowym, Dz.U. z 1922 r. nr 21, poz. 165.

Ustawa z 17.2.1922 r. o państwowej służbie cywilnej, Dz.U. z 1922 r. nr 21, poz. 164. 